\title{
Wild fruit use among early farmers in the Neolithic (5400-2300 cal BC) in the north-east of the Iberian Peninsula: an intensive practice?
}

\author{
Ferran Antolín · Stefanie Jacomet
}

Received: 31 December 2013/Accepted: 18 August 2014/Published online: 28 August 2014

(C) Springer-Verlag Berlin Heidelberg 2014

\begin{abstract}
The archaeobotanical record of 24 sites from the Neolithic period (5400-2300 cal BC) in the north-east of the Iberian Peninsula is evaluated. Remarkable amounts of data have recently been obtained for the early and middle Neolithic phases. Most of the studied sites were dry and they only yielded charred plant material. Among dry sites, several types of context were evaluated: dwelling areas, hearths, roasting pits and byres. Material was also analysed from a waterlogged cultural layer of one early Neolithic lakeshore site, La Draga. Quercus sp. (acorns), Corylus avellana L. (hazelnuts), Pistacia lentiscus L. (mastic fruits) and Vitis vinifera L. var. sylvestris (wild grapes) were among the most frequently encountered fruits and seeds. Their presence in the archaeobotanical record clearly maps their past ecological distribution in the region. There are differences observed between the charred dryland material and the waterlogged uncharred material. Wild fruits were mostly present in an uncharred state in La Draga. Therefore, their consumption could go unnoticed in dry sites when fruits were eaten raw or without roasting. Larger amounts of charred remains of certain wild fruits like acorns and hazelnuts found in mountain areas are highlighted as potential evidence of the regular practice of roasting, potentially indicating regional traditions. All in all, our results support an intensive wild plant use at least during the first 1,300 years of the Neolithic period. Evidence of wild plant food consumption becomes scanty
\end{abstract}

Communicated by S. M. Valamoti.

F. Antolín (ه) · S. Jacomet

Department of Environmental Sciences, Integrative Prehistory

and Archaeological Science (IPNA/IPAS), Basel University,

Spalenring 145, 4055 Basel, Switzerland

e-mail: ferran.antolin@unibas.ch towards the second phase of the middle and the late Neolithic (4th and 3rd millennium cal $\mathrm{BC}$ ). This, however, might also be due to taphonomic reasons.

Keywords Archaeobotany - Catalonia - Andorra - Wild edible plants · Taphonomy · Gathering

\section{Introduction}

There is convincing evidence that wild fruit gathering may have played an important role in the Neolithic economy. For instance, a study of the role of plants in the diet of the inhabitants of the Neolithic lakeshore site of Arbon Bleiche 3 in central Europe, based on the representation of uncharred plant macro-remains in waterlogged contexts, concluded that wild fruits were a very significant part of human diet, supplying a third of the caloric input of plant origin (Hosch and Jacomet 2004, pp 144-145). Can these observations be extrapolated to most Neolithic communities in Europe? And how was the use of wild fruits integrated in a farming economy? Was it organised at a household level? Who did most of the gathering activities? Was woodland managed or protected? What was the influence of the farming and social model on the concrete strategies of wild plant gathering? Were there local traditions?

Wild plant gathering strategies are frequently dealt with in ethnographic work. Some valuable case studies are known in the Mediterranean region, in Methana, Greece (Forbes 1976) and Kizilkaya, central Anatolia, Turkey (Ertug-Yaras 1997). In both cases, gathering was practised mainly by women. In Greece, gathering was usually not a specific task but something which was done while carrying out other activities, such as caring of grazing livestock, checking the state of crop fields, etc. Quite the opposite, in 
central Anatolia gathering was an activity which could last for two or three hours and was conducted in the vicinity of the settlement up to $1.5 \mathrm{~km}$ away from it. The inhabitants of the investigated villages in both areas used to eat wild vegetables as much as their own crops, which seems to reflect the previously mentioned results obtained at Arbon Bleiche 3. Are these the scenarios that one should expect for the Neolithic?

Significant advances have been made in the last decade towards a better characterization of the plant economy in the Neolithic of the Iberian Peninsula (Buxó and Piqué 2008; Peña-Chocarro et al. 2013). An important question which could never be properly investigated concerns the role of wild fruit gathering in the economy during the Neolithic (for interesting approaches in the western Pyrenees and the Basque country, see Zapata 2000; Zapata Peña et al. 2008). This work aims to address this issue, based on the large amount of new data recently obtained for the north-east of the Iberian Peninsula (Antolín 2013). Previously investigated sites will be included in our analysis. The diversity of studied contexts, both waterlogged and dry, allows the evaluation of an important factor that needs to be considered for a reliable approach to this topic, which is taphonomy: are all wild plants equally represented in waterlogged sediments and in dry sites? What information can be obtained from each type of site and what do the numbers obtained mean in palaeoeconomic terms?

Geographical, chronological and palaeoenvironmental framework

The northeast of the Iberian Peninsula is nowadays characterized by its climatic and ecological diversity, with the Pyrenees to the north, with Arctic-Alpine vegetation formations and boreal coniferous woods; the coast has a typical Mediterranean climate and Meso-thermomediterranean vegetation; the sub-Mediterranean zone, between the coast and the Pyrenees, has sub-Mediterranean woods of deciduous trees and pine, and the western Catalan plain has a continental climate. Barely any woods are found in the drier areas of this region (Fig. 1).

The Neolithic period (5400-2300 cal BC) in the northeast of the Iberian Peninsula can be divided into three phases: early Neolithic (5400-4500 cal BC), middle Neolithic (4500-3200 cal BC), and late Neolithic (3300/ 3000-2300 cal BC) (based on Barceló 2008).

Abundant palaeoenvironmental data is available for this region. In general, the percentages of arboreal pollen are much higher in the northern coastal region, from c. $90 \%$ in the 6 th to c. $75 \%$ towards the 3 rd millennium cal BC. In the central and southern coastal regions, arboreal pollen stays between 50 and $75 \%$ all over the sequence (Burjachs and Riera 1996). In the coastal area north of the river Llobregat,

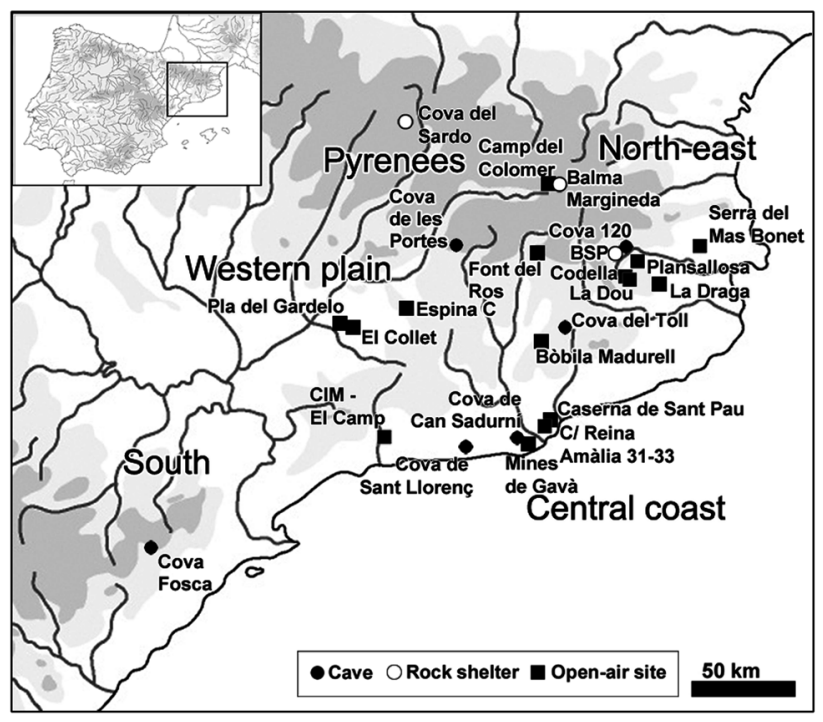

Fig. 1 Region under study, location of the sites and areas mentioned in the text

deciduous oak woods predominated during the middle Holocene (Riera Mora 2006). However, in the southern coastal region, a mixed woodland of evergreen and deciduous oaks is detected from the onset of the Neolithic. Maquis vegetation increased its significance towards the 4th and 3rd millennia cal BC (Riera Mora 2006; Riera et al. 2007). Recently, isotopic analyses identified one particularly drier phase between 4000 and 3000 Bс (Aguilera et al. 2012). The available data support a progressive climatic aridification during the middle Neolithic period (PérezObiol et al. 2011; see a more extensive compilation of literature in Antolín 2013).

\section{Materials and methods}

A total of 24 sites have been investigated in the region under study (Fig. 1; Table 1). There are 18 settlement phases from the early Neolithic, 14 from the middle Neolithic, and eight from the late Neolithic. Five sites are located in the Pyrenean region, seven in the north-eastern sector, seven in the central coastal region, three in the western plain and two in the southern half of the region. A total number of 252 contexts contained one or more plant macroremains. There were 89 for the early Neolithic, 134 for the middle Neolithic and 29 for the late Neolithic (for an overview see Table 1; the archaeological descriptions of the sites can be found in Antolín 2013). Only in one site, the early Neolithic lakeshore site of La Draga, Banyoles, Girona, were the conditions suitable for the preservation of uncharred material, only in Phase I, for which in this paper we will always refer to this phase when we mention the 


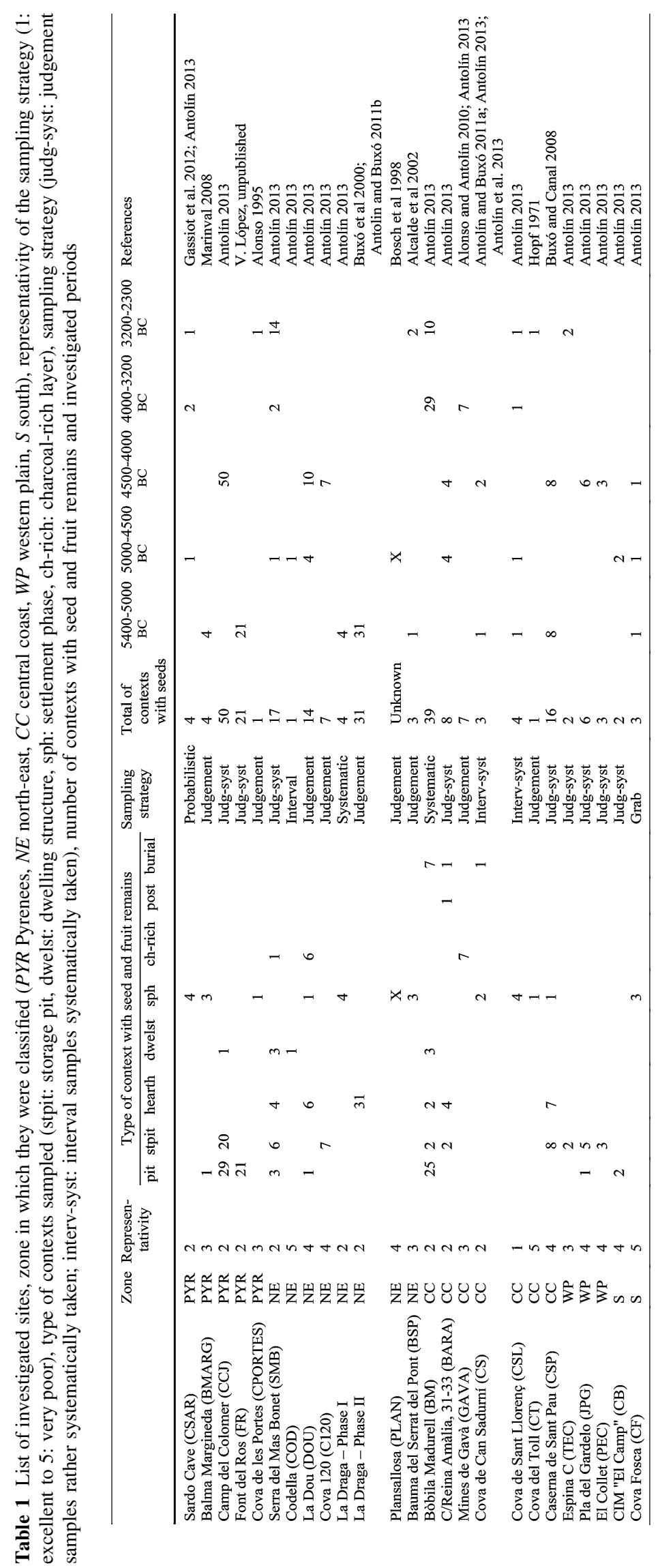


site. Otherwise, all remains were preserved in a carbonized state. Most of the contexts are secondary deposits (sensu Schiffer 1987), although some more or less in situ burnt assemblages were recovered in two (potentially three, if including the assemblage from Cova del Toll, in Moià, Barcelona, the sites of Cova de Can Sadurní, Begues, Barcelona (Antolín and Buxó 2011a) and La Draga (Antolín and Buxó 2011b; Antolín et al. 2014).

At least seven archaeobotanists have done analyses for this period and they have used several sampling strategies (Table 1; for further details on recovery techniques, see Antolín 2013). In order to evaluate the representativity of the soil sampling strategies carried out, the criteria developed by Jacomet and Brombacher (2005) were used.

The maximum quality (1) was given to those sites where sampling was carried out in more than 20 locations and different dwelling units (houses). Sites with a good representativity (2) are those for which more than ten locations were sampled but it is not known how many dwelling units could have existed, or insufficient volumes were taken. Sites with few systematic samples were considered as having a rather good representativity (3). Sites where only judgement samples were taken (but more than 20) were considered as poorly representative (4). Very poorly representative sites (5) are those for which less than five locations or contexts with a very bad preservation of archaeobotanical remains were sampled. The majority of sites have a good or very good representativity ( $n=10$ out of a total of 24) (Table 1$)$. The fact that most of the sites $(n=17)$ had less than 10 contexts with seed and fruit remains is because most of these sites $(n=12)$ did not have archaeological features, but rather a single archaeological layer, which was considered as one context. Therefore, even when the number of sampled contexts is low, this does not need to affect the representativity of the data. It should also be stressed that the sampling strategy at many sites is considered unrepresentative because the excavated area of the site was small.

All in all, c. 410,000 charred plant macroremains and 25,000 uncharred items have been recovered (Antolín 2013). Around 2,700 charred wild plant seeds and fruits were found (less than $1 \%$ of the total) while c. 18,100 uncharred items were identified (over $70 \%$ of the total).

For the identification of seeds and fruits, the IPAS reference collection, along with reference works (Cappers et al. 2006), were used (Fig. 2). The nomenclature of the taxa and the ecological groups in which they have been classified follows the Flora Manual dels Països Catalans (De Bolòs et al. 2005).

Seed and fruit remains were counted and scores were given for each type of fragment (Table 2) in order to calculate a minimum number of individuals (MNI; Table 3) and minimize the overrepresentation of very fragmented assemblages (Antolín 2013).

The edibility or medical properties of the taxa have been analysed by considering ethnobotanical data from the Mediterranean region (Tardío et al. 2006; Gausachs 2007, 2008), as well as the Plants for a Future database (www. pfaf.org), which classifies edibility and medicinal use of plants into rankings from 0 to 5 . Following the work of Colledge (personal communication), those taxa classified as Category 3 or above were considered as edible or with medicinal value. A total number of 64 taxa were selected on this basis. These were represented by around 1,400 charred remains (MNI) and 5,250 uncharred ones. Eightyseven contexts $(34.5 \%$ of the total of contexts with seed and fruit remains) had some remains of at least one of these 64 taxa.

Only those taxa which were either present in concentrations, or had been human-modified or appeared repeatedly in the record, either in more than $10 \%$ of the contexts, following Van der Veen (2007), or in more than one site per phase, were used for quantitative analyses in order to avoid casual finds.

\section{Results}

Early Neolithic (5400-4500 cal BC)

Forty taxa with food or medicinal value have been identified in 22 different contexts $(24.7 \%$ of the total number of contexts with seed and fruit remains) from 13 sites (Table 4). The best represented ecological group in the charred record on the basis of number of items and ubiquity is woodland vegetation. The uncharred record from the site of La Draga shows a different pattern, since lakeshore plants and plants from woodland edges and clearings are much better represented when only considering the number of remains.

Within the group of weeds and ruderals/pastures and grasslands, the significant presence of Chenopodium album, with a ubiquity of $18.2 \%$ of the contexts with wild fruits and present in three sites, and Apium graveolens, with relatively large numbers in one site, should be highlighted. Furthermore, the presence of Silybum marianum at La Draga is noteworthy, especially because its fruits were fragmented (Fig. 2).

Regarding the plants from woodland edges and clearings, it is worth emphasising the large numbers of Rubus fruticosus that were retrieved at La Draga, presenting some particular concentrations within the analysed surface of the site (Antolín 2013). Other edible fruits like Prunus spinosa and Crataegus monogyna were also identified, though in lower numbers. 


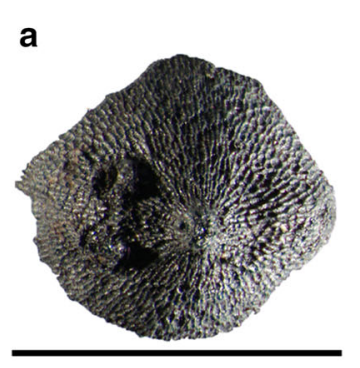

b

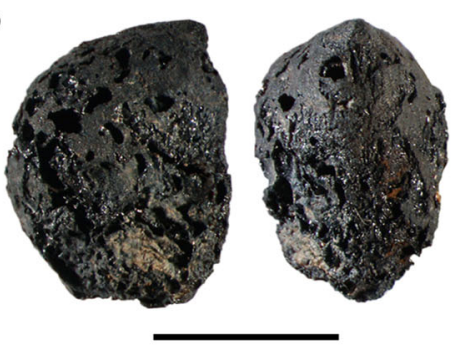

e
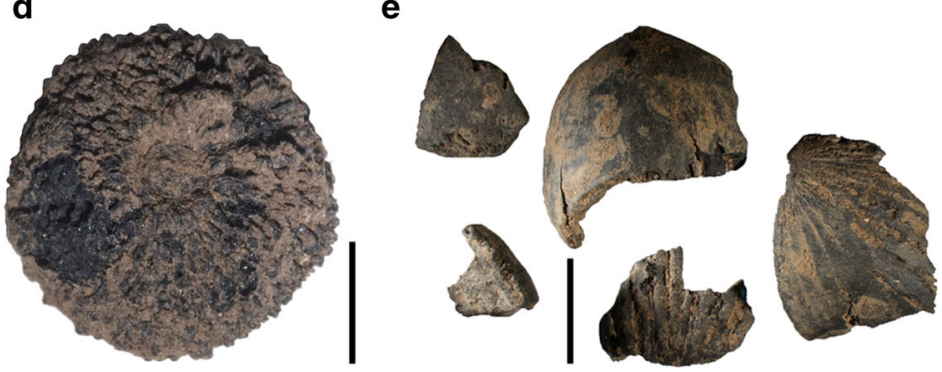

h

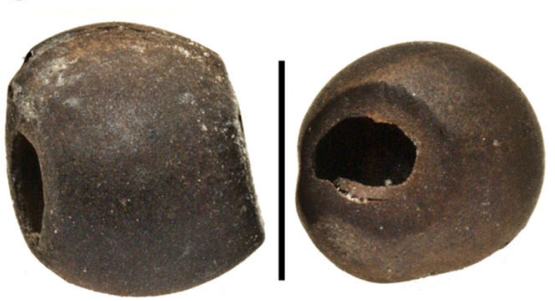

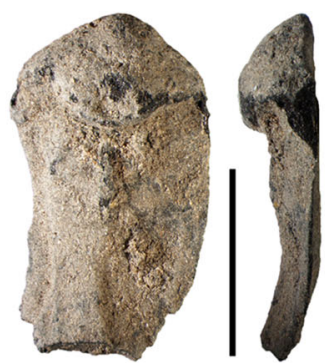

f

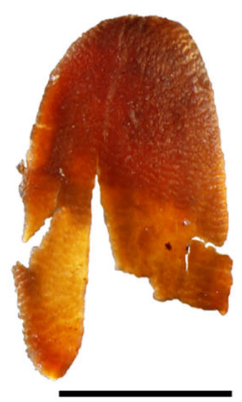

i

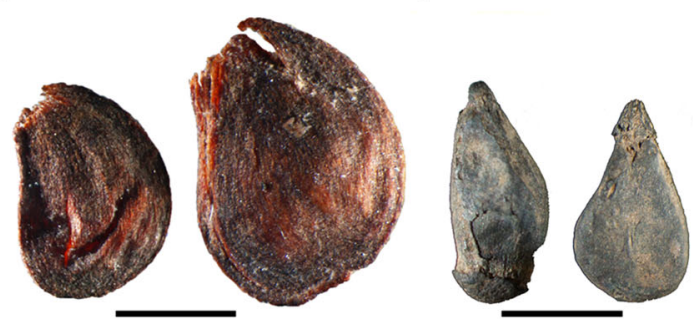

Fig. 2 Photos of some of the identified taxa: a Taxus baccata (Cova Fosca, Uzquiano et al. 2014); b Arctostaphylos uva-ursi (Cova Fosca); c Pinus sylvestris (Cova del Sardo); d Arbutus unedo (Cova de Can Sadurní); e Corylus avellana (Camp del Colomer); f Silybum marianum (La Draga); g, Beads made of stones of Prunus cf. avium
(La Draga, Antolín and Buxó 2011b); h Pyrus malus (La Draga); i Pyrus malus (Camp del Colomer). Horizontal scale bars $=3 \mathrm{~mm}$, vertical $=5 \mathrm{~mm}$. See the location of the sites in Fig. 1 and their chronology in Table 1; photos: F. Antolín

Among the taxa from woodland areas and maquis vegetation, Corylus avellana (present in eight sites and $68.2 \%$ of the contexts with wild fruits) and Quercus sp. (present in eight sites and $72.7 \%$ of the contexts with wild fruits) are the best represented, both considering the charred and the uncharred record. Other taxa like Pyrus malus and Prunus avium were only identified in an uncharred state, although there is one charred find of Prunus avium/mahaleb in Cova de Sant Llorenç, but in somewhat lower numbers. Pyrus malus has prolonged obovoid brownish to blackish flattish seeds (found both in charred and uncharred state, Fig. 2) with a finely reticulate-striate surface that gives the impression of the presence of longitudinal stripes (Jacomet et al. 1989, p 282; Torroba Balmori et al. 2013). Fragments of fruit flesh (found in charred form in Camp del Colomer) were identified by the regular and clear cell structure of the fruit flesh and the absence of stone cells typical of other fruits like Pyrus or Sorbus (Jacomet 2003, p 490). Besides 
Table 3 Formulae for the calculation of the MNI per taxon or type of remain (Antolín 2013). For a description of Types 1-3, see Table 2

\begin{tabular}{|c|c|}
\hline Taxon or group of taxa & Method for counting MNI \\
\hline Corylus shells (MNI) & $($ Fr. type $1 / 2+$ Fr. type $2+$ type 3$) / 8+$ half shell $/ 2+$ complete shell \\
\hline Quercus - kernels (ch) (MNI) & $($ Fr. type $1 / 2+$ Fr. type $2+$ type 3$) / 4+$ complete acorns \\
\hline Quercus - fruits (unch) (MNI) & Highest number between the pericarp fragments and bases \\
\hline Quercus - pericarp fragments (unch) & $($ Fr. type $1 / 2+$ Fr. type $2+$ type 3$) / 4+$ complete pericarp \\
\hline Quercus - bases (unch) & $\begin{array}{l}\text { (Fr. type } 2 / 2+\text { full bases) (fr. type } 1 \text { are counted when no type } 2 \text { are found } \\
\text { and only counted as } 1 \text {, no matter how many fragments) }\end{array}$ \\
\hline Arbutus unedo fruits (MNI) & (Fr. type $1 / 4+$ type 2$) / 2+$ whole fruits \\
\hline Cladium mariscus (MNI) & $\begin{array}{l}\text { Fr. with tip }+ \text { seed/fruit (fr. type } 1 \text { or without a tip are counted when } \\
\text { no type } 2 \text { are found, and only counted as } 1 \text {, no matter how many fragments) }\end{array}$ \\
\hline Rest of the taxa (MNI) & $\begin{array}{l}\text { Fr. type } 2+\text { complete seed or fruit (fr. type } 1 \text { are counted when no type } 2 \text { are } \\
\text { found, and only counted as } 1 \text {, no matter how many fragments) }\end{array}$ \\
\hline
\end{tabular}

this, the stones of Prunus avium were also used to make beads at La Draga (Antolín and Buxó 2011b; Fig. 2).

Concerning the lakeshore/riverine plants, only fruits of Vitis vinifera var. sylvestris appeared in more than one site, both in charred and uncharred form.

\section{Middle Neolithic (4500-3200 cal BC)}

Twenty-six taxa with edible or medicinal value were identified from the middle Neolithic phase (4500-3200 cal BC) in 11 sites and 58 contexts (43.3\% of the total number of contexts with seed and fruit remains) (Table 5). The best represented ecological groups are maquis and woodland taxa. Large numbers of some plants from woodland edges and clearings were found, but these were recovered in one single site each.

Among the weeds and ruderals, the repeated presence of Chenopodium album (17.2\% of the contexts with wild fruits) must be highlighted, especially in Camp del Colomer, Sant Julià de Lòria, Andorra, where it appears with a higher frequency. One more taxon is worth mentioning, Solanum nigrum, which was present in relatively large amounts.

Plants from woodland edges and clearings were probably intensively used on the sites where they were found; in general each taxon was found on one site only. One large concentration of stones of Crataegus monogyna was identified at La Dou, Sant Esteve d'en Bas, Girona (Buxó personal communication). Fragaria vesca was identified in several samples from Camp del Colomer.

The most important and diverse concentration of fruits from maquis with Arbutus unedo, Pistacia lentiscus and Olea europaea was found in Cova de Can Sadurní; Pistacia was identified in other sites of the western plain. Remains of Olea were found within a funerary context at mines de Gavà, Gavà, Barcelona (Buxó et al. 1991).

Concerning woodland taxa, it is of major interest to note that three taxa (Corylus, Quercus and Pyrus malus) were identified from Camp del Colomer in a charred state. They were found in almost pure concentrations but in different types of features. Quercus and Corylus were found primarily in small pits and in larger numbers, while smaller numbers of remains of Maloideae were found mainly in silo-type pits (for further details, see Antolín 2013).

Regarding lakeshore/riverine taxa, Vitis vinifera appeared in three sites, La Dou, mines de Gavà and Can Sadurní.

\section{Late Neolithic (3200-2300 cal BC)}

The available data for the late Neolithic period are meagre. Six taxa were identified in six sites and seven contexts (24.1\% of the total amount of contexts with seed and fruit remains) (Table 6). Nevertheless, the lack of archaeobotanical data is an important drawback for the general palaeoeconomic characterization of this period.

\section{Discussion}

Wild fruit taphonomy: charred vs. waterlogged preservation

The charred archaeobotanical record for the Neolithic period in the area under study is dominated by cereal remains (99\%, Antolín 2013). Nevertheless, the results obtained at La Draga are considerably different. Wild plant remains, both in a charred and uncharred state, make up $45.7 \%$ of the total assemblage. This percentage is even higher when only taking into consideration the uncharred record, in which nearly $75 \%$ of the assemblage belongs to wild fruits. When looking at the proportions of charred and uncharred remains per taxon at La Draga (Fig. 3), it becomes clear that the majority of remains were uncharred and, in some cases, such as Corylus or Pyrus malus, they were not recovered in a charred state. Given that an 
Table 4 Evaluation of the wild taxa identified in the northeast of the Iberian Peninsula for the early Neolithic period: sites and number of contexts in which they were found and number of remains according to preservation type

\begin{tabular}{|c|c|c|c|c|c|c|c|c|c|c|c|c|c|c|c|c|}
\hline $5400-4500$ cal. BC & 究 & $\sum_{\substack{\infty\\
}}^{0}$ & $\frac{\alpha}{x}$ & อి & ? & ర̇ & 学 & $\vec{n}$ & 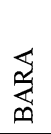 & రి & $\overrightarrow{0}$ & $\overrightarrow{\tilde{z}}$ & 毜 & Contexts (n) & $\begin{array}{l}\text { Charred } \\
\text { remains } \\
\text { (MNI) }\end{array}$ & $\begin{array}{l}\text { Uncharred } \\
\text { remains } \\
\text { (MNI) }\end{array}$ \\
\hline $\begin{array}{l}\text { Weeds, ruderals, pastures and grasslands } \\
\text { Apium graveolens } \mathrm{L} .\end{array}$ & & & & & & $X$ & & & & & & & & 3 & & 365 \\
\hline Atriplex patula L./latifolia Wahlenb. & & $\mathrm{X}$ & & & & & & & & & & & & 1 & 1 & \\
\hline Chenopodium album $\mathrm{L}$. & & & & & & $\mathrm{X}$ & & & & $\mathrm{X}$ & & $\mathrm{X}$ & & 4 & 2 & 139 \\
\hline Euphorbia helioscopia L. & & & & & & & & & $\mathrm{X}$ & & & & & 1 & 1 & \\
\hline Galium aparine L. s.l. & $\mathrm{X}$ & & & & & & & & & & & & & 4 & 9 & 1 \\
\hline Hypericum perforatum $\mathrm{L}$. & & & & & & $\mathrm{X}$ & & & & & & & & 3 & & 3 \\
\hline Polygonum aviculare L. & $\mathrm{X}$ & & & & $\mathrm{X}$ & & & & $\mathrm{X}$ & & & & & 3 & 2 & 34 \\
\hline Silybum marianum (L.) Gaertn. & & & & & & $\mathrm{X}$ & & & & & & & & 1 & & 2 \\
\hline Solanum nigrum L. & & & & & & & & & & $\mathrm{X}$ & & & & 1 & 9 & \\
\hline Stellaria media (L.) Vill.s.1. & & & & & & $\mathrm{X}$ & & & & & & & & 2 & & 2 \\
\hline Urtica dioica $\mathrm{L}$. & & & & & & $\mathrm{X}$ & & & & & & & & 3 & & 3 \\
\hline Vicia villosa Roth. & & & & & & $\mathrm{X}$ & & & & & & & & 1 & 1 & \\
\hline \multicolumn{17}{|l|}{ Woodland edges and clearings } \\
\hline Agrimonia eupatoria L. & & & & & & $\mathrm{X}$ & & & & & & & & 1 & & 1 \\
\hline Arctostaphylos uva-ursi (L.) Spreng. & & & & & & & & & & & & & $\mathrm{X}$ & 1 & 1 & \\
\hline Crataegus monogyna Jacq. & & & & & & $\mathrm{X}$ & & & & & & & & 1 & & 7 \\
\hline Origanum vulgare $\mathrm{L}$. & & & & & & $\mathrm{X}$ & & & & & & & & 2 & & 10 \\
\hline Prunus spinosa L. & & & & & & $\mathrm{X}$ & & & & & & & & 4 & & 10 \\
\hline Rubus fruticosus L. agg. & & & & & $\mathrm{X}$ & $\mathrm{X}$ & & & & & & & & 3 & 13 & 2,157 \\
\hline Rubus idaeus $\mathrm{L}$. & & & & & & & & & & $\mathrm{X}$ & & & & 1 & 1 & \\
\hline Vicia sepium L. & & & & & & $\mathrm{X}$ & & & & & & & & 1 & 3 & \\
\hline \multicolumn{17}{|l|}{ Maquis formations } \\
\hline Arbutus unedo L. & & & & & & & & & & $\mathrm{X}$ & & & & 1 & 5 & \\
\hline Pistacia lentiscus $\mathrm{L}$. & & & & & & & & & $\mathrm{X}$ & & $\mathrm{X}$ & & & 2 & 2 & \\
\hline \multicolumn{17}{|l|}{ Woodland } \\
\hline Abies alba Mill. & & & & & & & & & $\mathrm{X}$ & & & & & 1 & 1 & \\
\hline Corylus avellana $\mathrm{L}$. & $\mathrm{X}$ & $\mathrm{X}$ & $\mathrm{X}$ & $\mathrm{X}$ & $\mathrm{X}$ & $\mathrm{X}$ & & $\mathrm{X}$ & & & & & $\mathrm{X}$ & 15 & 86 & 20 \\
\hline Prunus avium (L.) L. & & & & & & $\mathrm{X}$ & & & & & & & & 3 & & 7 \\
\hline Prunus avium L./mahaleb L. & & & & & & & & & & & $\mathrm{X}$ & & & 1 & 1 & \\
\hline Prunus padus $\mathrm{L}$. & $\mathrm{X}$ & & & & & & & & & & & & & 1 & 1 & \\
\hline Pyrus malus subsp. sylvestris (L.) Ehrh. & & & & & & $\mathrm{X}$ & & & & & & & & 3 & & 11 \\
\hline Quercus sp. & & $\mathrm{X}$ & $\mathrm{X}$ & & & $\mathrm{X}$ & $\mathrm{X}$ & $\mathrm{X}$ & & $\mathrm{X}$ & $\mathrm{X}$ & & $\mathrm{X}$ & 16 & 81 & 147 \\
\hline Sorbus domestica L. & & & & & & & & & & & & & $\mathrm{X}$ & 1 & 2 & \\
\hline Taxus baccata $\mathrm{L}$. & & & & & & $\mathrm{X}$ & & & & & & & $\mathrm{X}$ & 2 & 1 & 1 \\
\hline \multicolumn{17}{|l|}{ Lakeshore } \\
\hline Alisma plantago-aquatica $\mathrm{L}$. & & & & & & $\mathrm{X}$ & & & & & & & & 3 & & 1,077 \\
\hline Alnus glutinosa (L.) Gaertn. & & & & & & $\mathrm{X}$ & & & & & & & & 3 & 11 & 7 \\
\hline Eupatorium cannabinum $\mathrm{L}$. & & & & & & $\mathrm{X}$ & & & & & & & & 2 & & 156 \\
\hline Mentha sp. & & & & & & $\mathrm{X}$ & & & & & & & & 3 & & 73 \\
\hline Phragmites australis (Cav.) Trin. s.1. & & & & & & $\mathrm{X}$ & & & & & & & & 1 & & 1 \\
\hline Plantago major L. & & & & & & $\mathrm{X}$ & & & & & & & & 2 & & 482 \\
\hline Scirpus lacustris L. & & & & & & $\mathrm{X}$ & & & & & & & & 3 & & 386 \\
\hline Vitis vinifera L. var. sylvestris & & & & & $\mathrm{X}$ & $\mathrm{X}$ & & & & & & & & 5 & 13 & 170 \\
\hline \multicolumn{17}{|l|}{ Aquatic } \\
\hline Nymphaea alba L. & & & & & & $\mathrm{X}$ & & & & & & & & 1 & & 1 \\
\hline
\end{tabular}


Table 5 Evaluation of the wild taxa identified in the northeast of the Iberian Peninsula for the middle Neolithic period: sites and number of contexts in which they were found and number of charred remains

\begin{tabular}{|c|c|c|c|c|c|c|c|c|c|c|c|c|c|}
\hline $4500-3200$ cal BC & 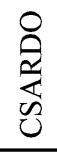 & $\bar{U}$ & ? & $\sum_{m}$ & $\underset{\nwarrow}{\overleftarrow{c}}$ & $\underset{\mho}{\longleftarrow}$ & $\tilde{U}$ & $\vec{\nabla}$ & 号 & i & 岂 & Contexts (n) & $\begin{array}{l}\text { Charred } \\
\text { remains } \\
\text { (MNI) }\end{array}$ \\
\hline \multicolumn{14}{|l|}{ Weeds and ruderals, pastures and grasslands } \\
\hline Artemisia vulgaris L. & & $\mathrm{X}$ & & & & & & & & & & 4 & 12 \\
\hline Atriplex patula $\mathrm{L}$. & & & & & & & $\mathrm{X}$ & & & & & 1 & 1 \\
\hline Capsella bursa-pastoris & & $\mathrm{X}$ & & & & & & & & & & 1 & 10 \\
\hline Chenopodium album $\mathrm{L}$. & & $\mathrm{X}$ & & & & & $\mathrm{X}$ & & & & & 10 & 24 \\
\hline Galium aparine L. s.l. & $\mathrm{X}$ & & $\mathrm{X}$ & & & & & & & & & 6 & 10 \\
\hline Hyoscyamus niger $\mathrm{L}$. & & $\mathrm{X}$ & & & & & & & & & & 1 & 4 \\
\hline Malva sp. & & & & & & & $\mathrm{X}$ & & & & & 1 & 1 \\
\hline Polygonum aviculare $\mathrm{L}$. & & $\mathrm{X}$ & & & & & & & & & & 1 & 1 \\
\hline Solanum nigrum $\mathrm{L}$. & & $\mathrm{X}$ & & & $\mathrm{X}$ & & $\mathrm{X}$ & & & & & 3 & 26 \\
\hline Thymus serpyllum L. & & $\mathrm{X}$ & & & & & & & & & & 2 & 14 \\
\hline Urtica dioica $\mathrm{L}$. & & $\mathrm{X}$ & & & & & & & & & & 6 & 53 \\
\hline \multicolumn{14}{|l|}{ Woodland edges and clearings } \\
\hline Crataegus monogyna Jacq. & & & $\mathrm{X}$ & & & & & & & & & 1 & 216 \\
\hline Fragaria vesca $\mathrm{L}$. & & $\mathrm{X}$ & & & & & & & & & & 7 & 181 \\
\hline Physalis alkekengi $\mathrm{L}$. & & $\mathrm{X}$ & & & & & & & & & & 1 & 2 \\
\hline Rubus fruticosus L. agg. & $\mathrm{X}$ & $\mathrm{X}$ & & & & & $\mathrm{X}$ & & & & & 4 & 6 \\
\hline Rubus idaeus $\mathrm{L}$. & $\mathrm{X}$ & & & & & & & & & & & 1 & 2 \\
\hline \multicolumn{14}{|l|}{ Maquis formations } \\
\hline Arbutus unedo L. & & & & & & & $\mathrm{X}$ & & & & & 2 & 233 \\
\hline Olea europaea L. var. sylvestris (Mill.) Brot. & & & & & & $\mathrm{X}$ & $\mathrm{X}$ & & & & & 4 & 178 \\
\hline Pistacia lentiscus L. & & & & $\mathrm{X}$ & & & $\mathrm{X}$ & & $\mathrm{X}$ & $\mathrm{X}$ & & 9 & 51 \\
\hline \multicolumn{14}{|l|}{ Woodland: diverse } \\
\hline Abies alba Mill. & $\mathrm{X}$ & & & & & & & & & & & 1 & 2 \\
\hline Corylus avellana $\mathrm{L}$. & $\mathrm{X}$ & $\mathrm{X}$ & $\mathrm{X}$ & & & & & & & & & 26 & 63 \\
\hline Pinus sylvestris L. & $\mathrm{X}$ & & & & & & & & & & & 1 & 1 \\
\hline Pyrus malus subsp. sylvestris (L.) Ehrh. & & $\mathrm{X}$ & & & & & & & & & & 5 & 18 \\
\hline Quercus sp. & & $\mathrm{X}$ & & & & & $\mathrm{X}$ & $\mathrm{X}$ & $\mathrm{X}$ & & $\mathrm{X}$ & 11 & 44 \\
\hline \multicolumn{14}{|l|}{ Riverside/wetland } \\
\hline Plantago major $\mathrm{L}$. & & $\mathrm{X}$ & & & & & & & & & & 2 & 3 \\
\hline Vitis vinifera L. var. sylvestris & & & $\mathrm{X}$ & & & $\mathrm{X}$ & $\mathrm{X}$ & & & & & 3 & 5 \\
\hline
\end{tabular}

extensive sampling has been done at the site, mainly focused on the recovery of charred plant remains, it is unlikely that these results are due to the representativity of the available data. If one considers these results as a model for the interpretation of charred assemblages, one should conclude that single finds of wild fruits with a clear economic use might reflect important resources in the economy of a settlement (Jacomet 2013). For this reason, they should be taken into consideration, especially on the basis of their ubiquity values, rather than on the absolute number of remains. The latter might have more to do with other taphonomic factors, such as the practice of roasting. This and other taphonomic processes related to the charring process favour the preservation of woody fruits and seeds, as noted by other authors (Jones 2000). As a result, the comparability between waterlogged and dry sites remains a problem that is still not properly solved and will be approached in an on-going project at IPAS, funded by the SNF, called "Formation and taphonomy of archaeological wetland deposits: two transdisciplinary case studies and their impact on lakeshore archaeology". 
Table 6 Evaluation of the wild taxa identified in the northeast of the Iberian Peninsula for the late Neolithic period: sites and number of contexts in which they were found and number of charred remains

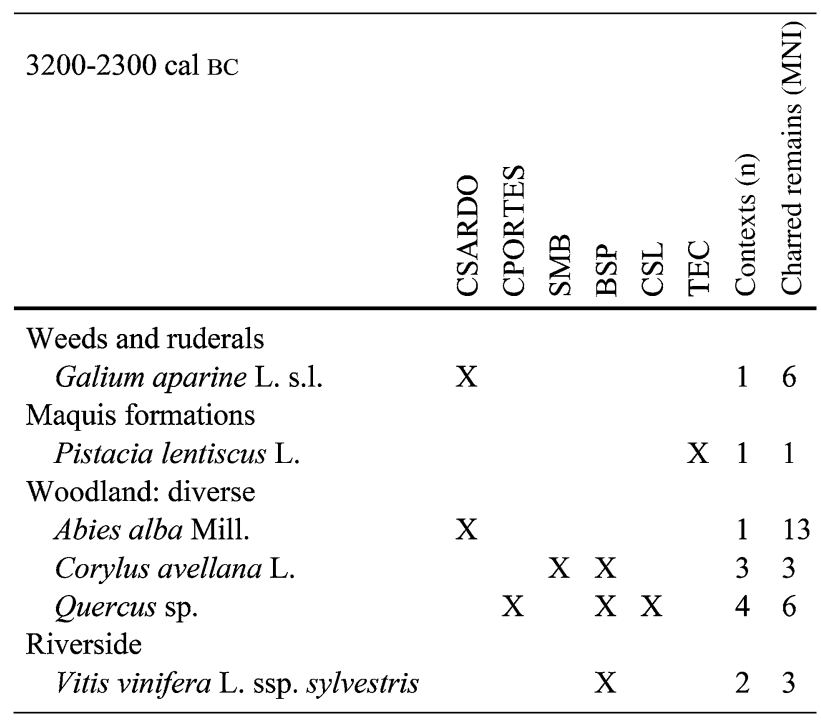

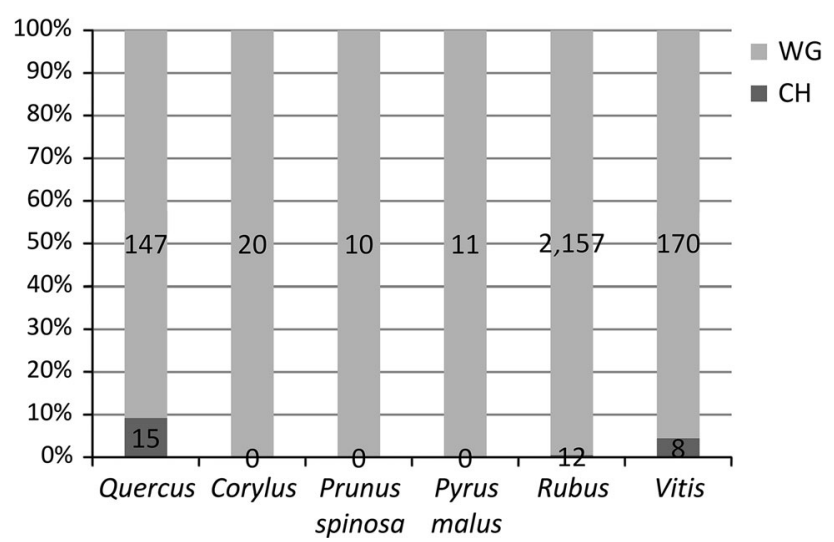

Fig. 3 Proportion of charred (ch) and uncharred (wg) remains of some of the better represented wild taxa of the Neolithic in the northeast of the Iberian Peninsula at La Draga (Sector D)

Wild fruit gathering: the use of different ecological groups

\section{Plants from ruderal areas, pastures and grasslands}

The interpretation of the economic use of plants from ruderal areas is not straightforward, since the seeds of these plants could have arrived at the site by multiple routes (Van der Veen 2007). At the same time, one might run the risk of underestimating their role as food plants. Our criteria for the selection of taxa (at the end of the methods and materials section) led us to the consideration of some particular taxa for the early and middle Neolithic.

First of all, Silybum marianum is the only taxon of this group which shows potential signs of human processing (pressing of the seeds). The seeds are in fragmented form (Fig. 2), similar to the finds from the early Neolithic site of La Marmotta (Lago de Bracciano, Italy; Rottoli 20002001). This fragmentation could have been caused by postdepositional processes, but it is significant that such finds were present in both sites and the possibility that they were used to produce oil should not be discarded. Chenopodium album was frequently represented in our samples. It could have been gathered for its seeds, which can be dried, parched and turned into flour (Maurizio 1927). It has been thought to be a gathered plant in many archaeobotanical investigations of the Neolithic period in Europe (Bogaard 2004b; Jacomet 2007; Behre 2008; Bakels 2009) and its presence in the colon contents of the some bog bodies (Hillman 1986; Harild et al. 2007) confirms that it was consumed in some areas during recent prehistory. Apium graveolens was only identified in La Draga, where it was probably growing locally. Some aerial parts, including fruits, of this plant have medicinal value but it is not possible to demonstrate that they could have been used for such purposes with the available evidence. Finally, Solanum nigrum was also relatively abundant in our samples. This plant is toxic and produces hallucinations, but it is known to have been eaten fresh in recent ethnobotanical work (Tardío et al. 2006). Solanum was identified in three different sites in rather different contexts of the middle Neolithic: secondary deposits in pits interpreted as resulting from the burning of dung (Camp del Colomer); a byre context at Cova de Can Sadurní, and a crop-rich assemblage at C/Reina Amàlia, 31-33, Barcelona (Antolín 2013). Therefore, it seems that it was not intentionally gathered.

\section{Plants from woodland edges and clearings}

This group is well represented in the early and middle Neolithic. Some concentrations of fruits were found in both periods. Firstly, assemblages rich in Rubus fruticosus found in La Draga could correspond to the accumulation of excrement (see, for instance, Maier 2001). Its consumption in a raw state was probably frequent at the site. Crataegus monogyna was found in large numbers in one hearth at $\mathrm{La}$ Dou, while some concentrations of Fragaria vesca were identified at Camp del Colomer. They were commonly gathered in other areas of Europe during the Neolithic (Jacomet 2007; Kohler-Schneider 2007; Bakels 2009). Their consumption is, consequently, very probable.

\section{Plants from maquis and woodland}

This was the best-represented group in all the analysed phases. Two different groups were distinguished: maquis and woodland. 
Concerning taxa from woodlands, beads of Prunus avium were recovered at La Draga, a unique find in the Iberian Peninsula and also very rare in later lakeshore sites of central Europe (Hosch and Jacomet 2004). In contrast, Corylus and Quercus are found in many contexts and sites in all periods. Pyrus malus is also well represented in some sites like Camp del Colomer, where it was recovered in silo-type pits, together with other remains suggesting human consumption, such as other edible wild fruits and cereals (Antolín 2013). The importance of hazelnuts, acorns and wild apples as gathered food resources in the Neolithic of the Iberian Peninsula was already stressed by Zapata (2000), and these are also important taxa in central Europe, mainly in the lake dwellings (Jacomet 2006, 2007), but also in other areas (Kreuz 2012).

Maquis vegetation becomes more evidently commonly used from the middle Neolithic onwards, and especially in the central coast and western plain areas. Analyses of soil micromorphology at Cova de Can Sadurní indicate that it was systematically used as a byre, and the preservation of charred fruits of Arbutus, which do not need of any processing with fire before consumption, fits well with a context of repeated burning of dung. Fruits could have incidentally fallen to the ground and then become charred during one of the many episodes of burning of dung layers. For this reason, they were interpreted at a hypothetical level as resulting from the use of branches of Arbutus unedo as well as Pistacia lentiscus and Olea europaea as leaf fodder (Antolín 2013; Antolín et al. 2013). This could only be confirmed through the analyses of dung pellets. There is evidence of keeping livestock in caves or rock shelters from several Neolithic sites across Europe (e.g. Delhon et al. 2008).

Finds of Pistacia in the western plain area, recovered from a variety of features, could be the result of the consumption of the fruits or the use of the seeds for making oil. They could also represent the frequent use of its wood as fuel (Piqué et al. 2012).

A concentration of fruit stones of Olea was found in a funerary context in the mines de Gavà, in association with a large amount of olive charcoal (Piqué 2010). Therefore it seems that they were not consumed. Nevertheless, wild olives are among the most frequent wild taxa found in the south of the Iberian Peninsula during the Neolithic (PérezJordà et al. 2011).

\section{Plants from the lakeshore/riverine woods}

Vitis vinifera var. sylvestris was recorded in all periods but in small numbers, which might be due to taphonomic factors. Wild grape has been identified in other areas of Europe as a gathered plant (Tolar Korencic et al. 2008), especially in southern Europe (Rovira 2007). It is very likely that it was also collected in our region.

Wild fruit gathering: chronological differences

The presented results do not show major changes in the list of the best-represented gathered taxa during the Neolithic period in the region discussed, which are Quercus sp., Corylus avellana, Vitis vinifera var. sylvestris and Pistacia lentiscus. However, some fluctuations can be highlighted regarding the ubiquity of each taxon in each phase (Fig. 4). It must be emphasized that the percentages obtained for the late Neolithic period might have a low representativity given the fact that the results were rather poor. P. lentiscus has a low ubiquity in the early Neolithic but it increases during the middle Neolithic. Quercus is very well represented in the early Neolithic and the late Neolithic, but not so frequently present during the middle Neolithic. Corylus is also widely represented in the early Neolithic and it decreases towards the middle and late Neolithic. Vitis is slightly more frequent in the early and late Neolithic, although with relatively low percentages. The changes in the records of Pistacia and Corylus agree with the climatic changes during the analysed period and other palaeoenvironmental proxies (Riera Mora 2006). The progressive drying of the climate would have contributed to the expansion of the former in the southern half of the area studied and the decrease of latter in the lowlands.

It is worth noting that the largest proportion of samples with wild fruits was found in the middle Neolithic (c. $43 \%$ ), precisely the period for which more samples were
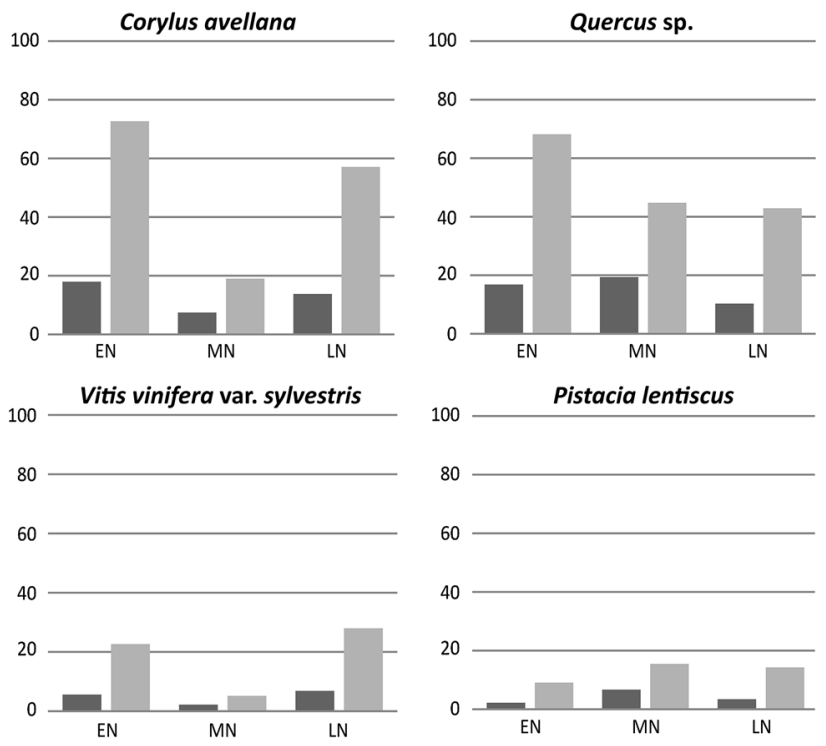

Fig. 4 Ubiquity values of the best-represented wild taxa considering the total number of contexts (light grey) and the number of contexts with wild fruit remains (dark grey) 
analysed, which makes this percentage more significant. This speaks in favour of their intensive gathering during this phase. An important general decrease in the number of remains recovered for the late Neolithic was observed. This is attested for the whole archaeobotanical record and such a decrease is also observed in other intensively investigated areas in recent times (Whitehouse et al. 2013). Taphonomic reasons might be behind this apparent decrease. In fact, the similar ubiquity percentages for the early and late Neolithic periods (around $24 \%$ ) are an indication that the decrease during the late Neolithic is not as pronounced as one might assume by looking at the absolute number of remains.

\section{Wild fruit gathering: regional differences}

When looking at the distribution of the archaeobotanical finds of the most relevant taxa per zone (Fig. 5) one can observe that large numbers of Corylus avellana were only recovered in the northern Pyrenean and southern mountainous areas. This contrasts with its low representation in the northeastern area, where it was also present according to pollen and charcoal data (Piqué 2005; Riera Mora 2006). The results from uncharred remains obtained at La Draga demonstrate that hazelnuts were consumed in the area, but they were not found in a charred state (Fig. 3). Consequently, scarcity of hazel in the record of this area might be due to taphonomic factors, for example because hazelnuts were not roasted, but eaten raw. Quercus sp. (probably various species with different ecologies) presents a similar problem. It was recovered in the entire studied region, but large amounts were only present in the northern and southern mountainous areas. Another such example from a nearby region, the southern side of the central Pyrenees, and dated to the early Neolithic (c. $5400 \mathrm{cal} \mathrm{BC}$ ), can be found in cueva de Chaves where relatively large amounts of charred acorns were recovered (Zapata Peña et al. 2008). These data suggest that the small numbers of acorns which have been found in the western plain and central coastal areas do not correspond to the rarity of Quercus in the environment or to the fact that acorns were not consumed, but rather to the type of processing of this resource. Acorns could have been consumed in other ways, raw or boiled and ground, given that sweet varieties of acorn were available in the Mediterranean region (Oliveira et al. 1991; Mason and Nesbitt 2009).

Vitis was only found in the eastern region, mostly linked to riverine or lakeshore sites. It is better represented during the early Neolithic. Pistacia stones, along with Olea and Arbutus unedo, which are not shown in the graphs, were found in the central coastal area from the middle Neolithic onwards and they were also present on the western plain. The distribution of the sites where the consumption of these taxa is observed seems to be restricted to the areas

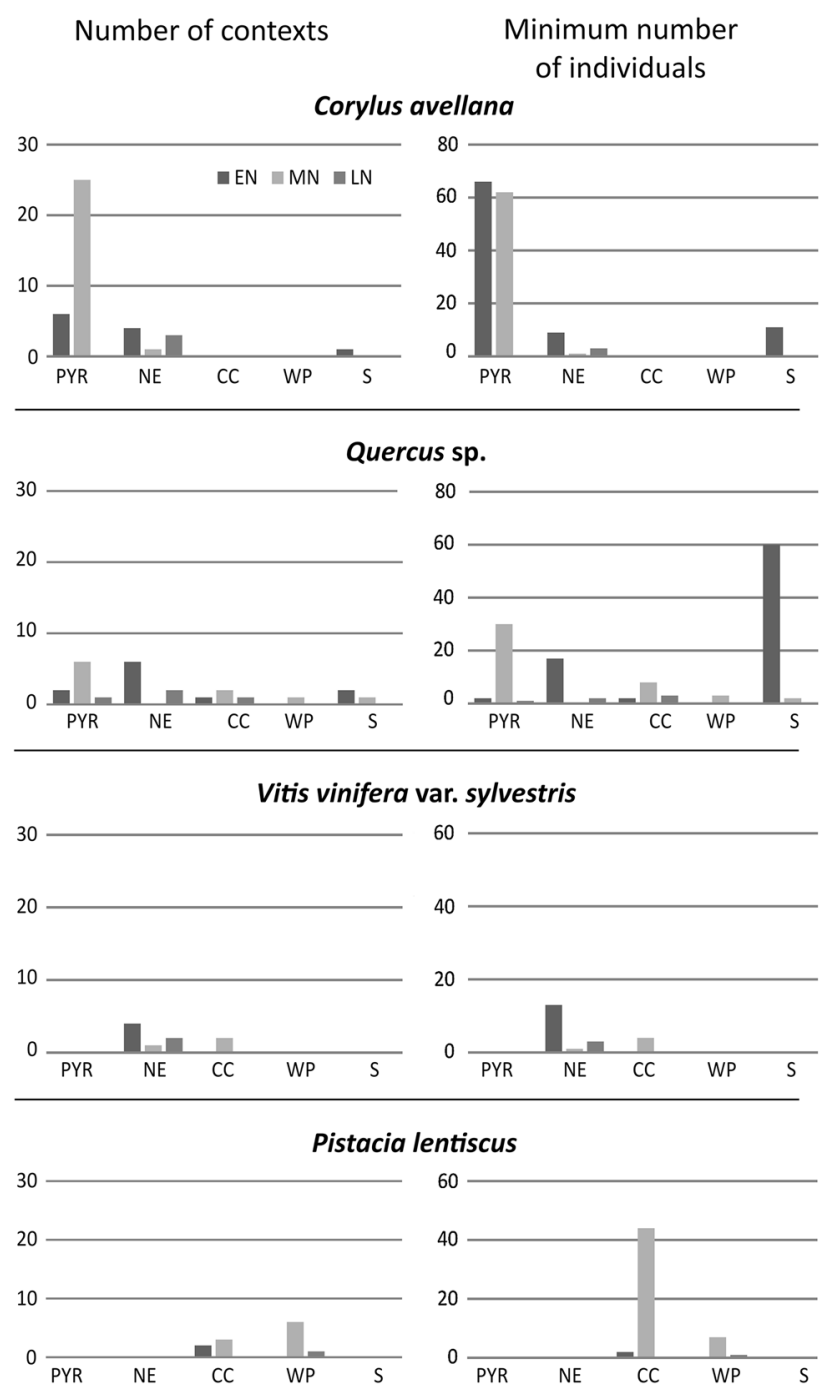

Fig. 5 Number of contexts and MNI per taxon (charred preservation), period and region ( $P Y R$ Pyrenees, $N E$ north-east, $C C$ central coast, $W P$ western plain, $S$ south)

where they were ecologically available, which is an indication of the local uses of resources by each community.

Our results mirror on the one hand the ecological differences between the mentioned areas and, on the other, they also show potential economic and cultural differences, especially in the way in which certain taxa were processed. Given the long duration of these differences, one could speculate that wild plant gathering strategies were locally transmitted and maintained over generations.

Wild fruit gathering: an intensive practice in the Neolithic?

B. Smith defines "niche construction" in small-scale preindustrial societies as the active participation of those populations in the shaping of the environment to their liking, by means of sowing wild annuals or transplanting 
perennial wild plants (more labour-intensive activities) as well as burning wild vegetation stands (less labour intensive activities) for various purposes (Smith 2011). It is our working hypothesis that the higher or lower intensity of the management of wild and domestic plant resources are interconnected. The interrelation between wild plant gathering and farming models has not been considered in many studies, but there are several indicators that suggest that some models are more compatible than others. For instance, the example presented in the introduction for Kizilkaya (Ertug-Yaras 1997) can only be carried out when wild vegetation stands are close to the dwelling area. Overexploitation can have a negative impact on wild food availability, for which sufficiently large woodland areas are necessary for a sustained use of wild fruits over time. This is less compatible with very extensive farming regimes, which make a significant contribution to the decline in the availability of wild foods (Bharucha and Pretty 2010). Recent work on agroecology and food sovereignty shows that multi-cropping intensive farming methods provide enough food from small plots and, at the same time, make the intensive gathering of wild fruits from well-developed woodland more compatible (Altieri et al. 2012). This model also results in the protection and incorporation of wild plants into home gardens, such as Silybum marianum or Fragaria vesca, in order to consume them as fruit, vegetables or for medicinal purposes (Agelet et al. 2000; Salako et al. 2014). This would make intensive farming practices more compatible with the intensive management of wild resources. In the framework of shifting agriculture models, one would expect a significant impact on the type of wild fruits gathered, given the important ecological imprint of such practices on the woodland cover, as observed in the modelling work carried out by Baum (2014). Most of the gathering would have taken place in secondary woodland, rather than in well-developed woods (Bharucha and Pretty 2010) and it seems unlikely that such practices were combined with the transplantation of wild trees, for instance. Even in intensely managed swidden fallows such as the ones known at present in southeast Asia (Rerkasem et al. 2009), the strategies are oriented to enhance different natural successional stages that can provide a large diversity of wild fruits, rather than the transplanting or sowing of wild plants. It is clear that more work is needed for a better understanding of the interrelation between wild plant gathering practices and crop husbandry. Only interdisciplinary analyses and more ethnographic work that combines both types of evidence can help to disentangle this question.

In our study, edible or medicinal wild plant taxa are present in almost all the investigated Neolithic sites. According to their present ecological classification, woodland and maquis vegetation were the most frequently used ecosystems. This would indicate that woods were close to the villages, as indicated by pollen analyses (see references above), and consequently, they could be frequently visited, as in intensive systems. Following the same logic of the argument, the low representation of edible ruderal taxa might be due to the small number of fallow or abandoned fields in the immediate surroundings of the settlements, also as in intensive systems. Recent archaeobotanical evaluations have presented intensive farming (sensu Bogaard 2004a) as the most plausible option for farming practices in the region, at least during the early Neolithic (Antolín 2013; Antolín et al. 2014). Alternatively, one should also consider the possibility that ruderal plants are underrepresented in dry sites because they were eaten as green vegetables.

\section{Conclusions}

Recent investigations have allowed a detailed approach to wild plant gathering in the northeast of the Iberian Peninsula during the Neolithic. However, some periods (late Neolithic) and areas (western plain and southern area) are not well represented in our database, probably due to taphonomic reasons. The charred record was found to be quantitatively unreliable in order to establish the importance of gathered plants in the diet (sensu Hosch and Jacomet 2004), due to taphonomic issues that make the number of recovered items largely unrepresentative. Nevertheless, the repeated presence of certain taxa, or their recovery in concentrations was considered useful to give hints on the role of wild plant gathering in the economy of the group.

Evidence of wild fruit gathering was recovered in almost all sites and all regions. Quercus sp., Corylus avellana, Vitis vinifera var. sylvestris and Pistacia lentiscus were the most commonly found taxa, but other plants were also gathered. The systematic use of woodland resources is considered as supporting evidence for an intensive model of management. Potential regional patterns are distinguished, including the practice of roasting acorns, hazelnuts and apples/pears, only proposed for mountain areas. New criteria have been recently established to identify the deliberate roasting of hazelnuts (López-Dóriga 2013; Berihuete Azorín and Antolín 2014). Such an evaluation would be of much interest for the future. Maquis vegetation seems to have been systematically used from the middle Neolithic onwards in the central coast and western plain sectors.

Acknowledgments We would like to thank all the archaeologists who supplied samples for archaeobotanical studies. FA wishes to thank R. Piqué (Universitat Autònoma de Barcelona) and R. Buxó for 
guidance during the elaboration of his doctorate. Thanks to Ö. Akeret (IPAS) for helping with difficult identifications. We acknowledge S. M. Valamoti and two anonymous reviewers for their insightful comments on an earlier version of this paper and J. Greig as copy editor.

\section{References}

Agelet A, Bonet MA, Vallès J (2000) Homegardens and their role as a main source of medicinal plants in mountain regions of Catalonia (Iberian Peninsula). Econ Bot 54:295-309

Aguilera M, Ferrio J, Pérez G, Araus J, Voltas J (2012) Holocene changes in precipitation seasonality in the Western Mediterranean Basin: a multi-species approach using $\delta 13 \mathrm{C}$ of archaeobotanical remains. J Quat Sci 27:192-202

Alcalde G, Molist M, Saña M (2002) Procés d'ocupació de la Bauma del Serrat del Pont, La Garrotxa, entre 5480 i 2900 cal AC. Museu Comarcal de la Garrotxa, Olot

Alonso N (1995) Estudi de llavors i fruits dels jaciments arqueobotànics de la cova d'Anes (Prullans, la Cerdanya) i de la cova de les Portes (Lladurs, El Solsonès) i el seu context Pirinenc. Xè Colloqui Internacional d'Arqueologia de Puigcerdà 1994:97-104

Alonso N, Antolín F (2010) Mostreig, tractament i anàlisi arqueobotànica de llavors i fruits d'època neolítica al sector de la Serra de les Ferreres de les Mines de Gavà. Rubricatum, Revista del Museu de Gavà 4:205-206

Altieri MA, Funes-Monzote FR, Petersen P (2012) Agroecologically efficient agricultural systems for smallholder farmers: contributions to food sovereignty. Agron Sustain Dev 32:1-13

Antolín F (2013) Of cereals, poppy, acorns and hazelnuts. Plant economy among early farmers (5400-2300 cal BC) in the NE of the Iberian Peninsula. An archaeobotanical approach. Dissertation, Universitat Autònoma de Barcelona, http://hdl.handle.net/ 10803/128997. Accessed 20 Dec 2013

Antolín F, Buxó R (2011a) Proposal for the systematic description and taphonomic study of carbonized cereal grain assemblages: a case study of an early Neolithic funerary context in the cave of Can Sadurní (Begues, Barcelona province, Spain). Veget Hist Archaeobot 20:53-66

Antolín F, Buxó R (2011b) L'explotació de les plantes: contribució a la història de l'agricultura i de l'alimentació vegetal del Neolític a Catalunya. In: Bosch A, Chinchilla J, Tarrús J (eds) El poblat lacustre del Neolític antic de La Draga. Excavacions 2000-2005. (Monografies del CASC 9) CASC, Girona, pp 147-174

Antolín F, Buxó R, Piqué R, Edo M (2013) L'aprofitament dels recursos vegetals silvestres al jaciment de la Cova de Can Sadurní. Des de l'Epipaleolític al Neolític final. In: Diputació de Barcelona (ed) VI Monografies del Garraf i d'Olèrdola. (Sèrie Territori 22) Diputació de Barcelona, Barcelona, pp 151-172

Antolín F, Buxó R, Jacomet S et al (2014) An integrated perspective on farming in the Early Neolithic lakeshore site of La Draga (Banyoles, Spain). Environ Archaeol. doi:10.1179/1749631414Y. 0000000027

Bakels CC (2009) The Western European loess belt. Agrarian history, 5300 BC-AD 1000. Springer, New York

Barceló JA (2008) La seqüència crono-cultural de la prehistòria catalana. Anàlisi estadística de les datacions radiomètriques. Cypsela 17:65-88

Baum TG (2014) Models of wetland settlement and associated land use in South-West Germany during the fourth millennium BC. Veget Hist Archaeobot 23(Suppl 1):S67-S80

Behre KE (2008) Collected seeds and fruits from herbs as prehistoric food. Veget Hist Archaeobot 17:65-73
Berihuete Azorín M, Antolín F (2014) A les avellanes, foc i flames: Tafonomia i quantificació de les closques d'avellana recuperades en contextos arqueològics. Revisió del registre documentat a la Península Ibèrica. Cypsela 19

Bharucha Z, Pretty J (2010) The roles and values of wild foods in agricultural systems. Philos Trans R Soc Lond Ser B: Biol Sci 365:2913-2926

Bogaard A (2004a) The nature of early farming in Central and Southeast Europe. Doc Praehist 31:49-58

Bogaard A (2004b) Neolithic farming in central Europe. Routledge, London

Bosch A, Buxó R, Palomo A et al (1998) El Poblat neolític de Plansallosa: L'explotació del territori dels primers agricultorsramaders de l'Alta Garrotxa. Museu Comarcal de la Garrotxa, Olot

Burjachs F, Riera S (1996) Canvis vegetals i climàtics durant el Neolític a la façana mediterrània ibèrica. Rubricatum, Revista del Museu de Gavà 1:21-25

Buxó R, Canal D (2008) L'agricultura i l'alimentació vegetal. Quarhis 4:54-56

Buxó R, Piqué R (2008) Arqueobotánica: los usos de las plantas en la Península Ibérica. Ariel, Barcelona

Buxó R, Buxó R, Català M, Villalba MJ (1991) Llavors i fruits en un conjunt funerari situat en la galeria d'accés a la mina 28 del complex miner de Can Tintorer (Gavà). Cypsela 9:65-72

Buxó R, Rovira N, Sauch C (2000) Les restes vegetals de llavors i fruits. In: Bosch A, Chinchilla J, Tarrús J (eds) El poblat lacustre neolític de La Draga. Excavacions de 1990 a 1998. (Monografies del CASC 2) CASC, Girona, pp 129-140

Cappers RTJ, Bekker RM, Jans JEA (2006) Digital seed atlas of the Netherlands. Barkhuis, Groningen

De Bolòs O, Vigo J, Masalles RM, Ninot JM (2005) Flora manual dels Països Catalans, 3rd edn. Pòrtic, Barcelona

Delhon C, Martin L, Argant J, Thiébault S (2008) Shepherds and plants in the Alps: multi-proxy archaeobotanical analysis of neolithic dung from "La Grande Rivoire" (Isère, France). J Archaeol Sci 35:2937-2952

Ertug-Yaras F (1997) An ethnoarchaeological study of subsistence and plant gathering in central Anatolia. Doctoral thesis, Washington University. UMI Dissertation Services, St. Louis

Forbes MHC (1976) Gathering in the Argolid: a subsistence subsystem in a Greek agricultural community. Ann N Y Acad Sci 268:251-264

Gassiot E, Rodríguez-Antón D, Burjachs F, Antolín F, Ballesteros A (2012) Poblamiento, explotación y entorno natural de los estadios alpinos y subalpinos del Pirineo Central durante la primera mitad del Holoceno. Cuaternario y Geomorfologia 26:29-45

Gausachs R (2007) Les herbes remeieres. De la cultura popular al fàrmac. Una aproximació etnobotànica, vol 1. Rafael Dalmau, Barcelona

Gausachs R (2008) Les herbes remeieres. De la cultura popular al fàrmac. Una aproximació etnobotànica, vol 2. Rafael Dalmau, Barcelona

Harild JA, Robinson DE, Hudlebusch J (2007) New analyses of Grauballe Man's gut contents. In: Asingh P, Lynnerup N (eds) Grauballe man: an iron age bog body revisited. (Jutland Archaeological Society Publications 49) Jutland Archaeological Society, Moesgaard, pp 154-87

Hillman GC (1986) Plant foods in ancient diet: the archaeological role of palaeofaeces in general and Lindow man's gut contents in particular. In: Stead M, Bourke JB, Brothwell D (eds) Lindow man: the body in the bog. British Museum, London, pp 99-202

Hopf M (1971) Vorgeschichtliche Pflanzenreste aus Ostspanien. Madrider Mitt 12:101-114 
Hosch S, Jacomet S (2004) Ackerbau und Sammelwirtschaft. Ergebnisse der Untersuchung von Samen und Früchten. In: Jacomet S, Leuzinger U, Schibler J (eds) Die jungsteinzeitliche Seeufersiedlung Arbon Bleiche 3. Umwelt und Wirtschaft. (Archäologie im Thurgau 12) Amt für Archäologie des Kanton Thurgau. Frauenfeld, pp 112-157

Jacomet S (2003) Und zum Dessert Granatapfel - Ergebnisse der archäobotanischen Untersuchungen. In: Hagendorn A et al. (eds) Zur Frühzeit von Vindonissa: Auswertung der Holzbauten der Grabung Windisch-Breite 1996-1998. (Veröffentlichungen der Gesellschaft Pro Vindonissa 18) Gesellschaft Pro Vindonissa, Brugg, pp 173-229

Jacomet S (2006) Plant economy of the northern Alpine lake dwelling area: 3500-2400 cal. BC. In: Karg S, Baumeister R, Schlichtherle H, Robinson DE (eds) Economic and environmental changes during the 4th and 3rd Millenia BC. Environ Archaeol 11:64-83

Jacomet S (2007) Neolithic plant economies in the northern Alpine Foreland from 5500-3500 cal BC. In: Colledge S, Conolly J (eds) The origins and spread of domestic plants in Southwest Asia and Europe. Left Coast Press, Walnut Creek, pp 221-258

Jacomet S (2013) Archaeobotany: the potential of analyses of plant remains from waterlogged archaeological sites. In: Menotti F, O'Sullivan A (eds) The Oxford handbook of wetland archaeology. Oxford University Press, Oxford, pp 497-514

Jacomet S, Brombacher C (2005) Reconstructing intra-site patterns in Neolithic lakeshore settlements: the state of archaeobotanical research and future prospects. In: Trachsel M (ed) Della Casa P. Wetland economies and societies. Chronos, Zürich, pp 69-94

Jacomet S, Brombacher C, Dick M (1989) Archäobotanik am Zürichsee. Zürcher Denkmalpflege, Zürich

Jones G (2000) Evaluating the importance of cultivation and collecting in Neolithic Britain. In: Fairbairn AS (ed) Plants in Neolithic Britain and beyond. (Neolithic Studies Group Seminar Papers 5) Oxbow, Oxford, pp 79-84

Kohler-Schneider M (2007) Early agriculture and subsistence in Austria: a review of Neolithic plant records. In: Colledge S, Conolly $\mathbf{J}$ (eds) The origins and spread of domestic plants in Southwest Asia and Europe. Left Coast Press, Walnut Creek, pp 209-220

Kreuz A (2012) Die Vertreibung aus dem Paradies? Archäobiologische Ergebnisse zum Frühneolithikum im westlichen Mitteleuropa. Ber RGK 91:23-196

López-Dóriga IL (2013) An experimental approach to the taphonomic study of charred hazelnut remains in archaeological deposits. Archaeol Anthr Sci. doi:10.1007/s12520-013-0154-3

Maier U (2001) Archäobotanische Untersuchungen in der neolithischen Ufersiedlung Hornstaad-Hörnle IA am Bodensee. In: Maier U, Vogt R (eds) (Siedlungsarchäologie im Alpenvorland 6) Forsch Ber Vor- Frühgesch Bad-Württ 74. Theiss, Stuttgart, pp 9-384

Marinval P (2008) Dades complementàries sobre l'economia vegetal de l'Epipaleolític i el Mesolític de la Balma de la Margineda. In: Guilaine J, Martzluff M (eds) Les excavacions de la Balma de la Margineda (1979-1991), vol 4. Edicions del Govern d'Andorra, Andorra, pp 480-491

Mason SLR, Nesbitt M (2009) Acorns as food in southeast Turkey: implications for prehistoric subsistence in Southwest Asia. In: Fairbairn A, Weiss E (eds) From foragers to farmers. Papers in honour of Gordon C. Hillman, Oxbow, Oxford, pp 71-85

Maurizio A (1927) Die Geschichte unserer Pflanzennahrung von den Urzeiten bis zur Gegenwart. Parey, Berlin

Oliveira F, Queiroga F, Pereira A (1991) O pão de bolota na cultura castreja. In: Queiroga F, Dinis AP (eds) Paleoecologia e Arqueologia. Centro de Estudios Arqueológicos Famalicenses, Vila Nova de Famalicão, pp 251-268
Peña-Chocarro L, Pérez-Jordà G, Morales J, Zapata L (2013) Neolithic plant use in the Western Mediterranean region: preliminary results from the AGRIWESTMED project. Ann di Bot 3:135-141

Pérez-Jordà G, Peña-Chocarro L, Morales J (2011) Agricultura neolítica en Andalucía. Menga. Revista de Prehistoria de Andalucía 2:59-71

Pérez-Obiol R, Jalut G, Julià R, Pèlachs A, Iriarte MJ, Otto T, Hernández-Beloqui B (2011) Mid-Holocene vegetation and climatic history of the Iberian Peninsula. Holocene 21:75-93

Piqué R (2005) Paisaje y gestión de recursos forestales entre el VI y IV milenio cal $\mathrm{BC}$ en el nordeste de la Península Ibérica. In: Arias P, Ontañón R, García-Moncó C (eds) Actas del III Congreso del Neolítico en la Península Ibérica: Santander, 5 a 8 de octubre de 2003. Universidad de Cantabria, Cantabria, pp 45-52

Piqué R (2010) Les fustes carbonitzades d'època neolítica de les mines 83, 84, 85 i 90 de Gavà. Rubricatum, Revista del Museu de Gavà 4:193-199

Piqué R, Vila Moreiras S, Alonso N (2012) Changes in vegetation and fuel use from the Neolithic to the Middle Ages in the Western Catalan plain. In: Badal García E, Carrión Marco Y, Macías Enguídanos M, Ntinou M (eds) Wood and charcoal: evidence for human and natural history. (Sagvntvm Extra-13) Universitat de València, Valencia, pp 85-96

Rerkasem K, Lawrence D, Padoch C, Schmidt-Vogt D, Ziegler AD, Bruun TB (2009) Consequences of swidden transitions for crop and fallow biodiversity in Southeast Asia. Hum Ecol 37:347-360

Riera Mora S (2006) Cambios vegetales holocenos en la región mediterránea de la Península Ibérica: ensayo de síntesis. Ecosistemas 15:22-35

Riera S, Esteve X, Nadal J (2007) Systèmes d'exploitation et anthropisation du paysage méditerranéen du Néolithique ancien au premier âge du Fer: le cas de la dépression de Penedès (nordest de la péninsule ibérique). In: Richard H, Magny M, Mordant $\mathrm{C}$ (eds) Environnements et cultures à l'âge du Bronze en Europe Occidentale. (Actes des congrès nationaux des Sociétés historiques et scientifiques129e, Besançon, 2004) Editions du CTHS, Paris, pp 121-141

Rottoli M (2000-2001) Zafferanone selvatico (Carthamus lanatus) e cardo della Madonna (Silybum marianum), piante raccolte o coltivate nel Neolitico antico a "La Marmotta"? Bullettino di Paletnologia Italiana (Roma) 91-92:47-61

Rovira N 2007 Agricultura y gestión de los recursos vegetales en el sureste de la Península Ibérica durante la Prehistoria reciente. Dissertation, Universitat Pompeu Fabra, http://hdl.handle.net/ 10803/7468. Accessed 1 Dec 2013

Salako VK, Fandohan B, Kassa B, Assogbadjo AE, Idohou AFR, Gbedomon RC et al (2014) Home gardens: an assessment of their biodiversity and potential contribution to conservation of threatened species and crop wild relatives in Benin. Genet Resour Crop Evol 61:313-330

Schiffer MB (1987) Formation processes of the archaeological record. University of New Mexico Press, Albuquerque

Smith BD (2011) General patterns of niche construction and the management of "wild" plant and animal resources by smallscale pre-industrial societies. Phil Trans R Soc B 366:836-848

Tardío J, Pardo-de-Santayana M, Morales R (2006) Ethnobotanical review of wild edible plants in Spain. Bot J Linn Soc 152:27-71

Tolar Korenčič T, Jakše J, Korošec-Koruza Z (2008) The oldest macroremains of Vitis from Slovenia. Veget Hist Archaeobot 17(Suppl 1):S93-S102

Torroba Balmori P, Zaldívar García P, Hérnandez Lázaro Á (2013) Semillas de frutos carnosos del norte ibérico. Guia de identificación. (Serie Ciencias 26) Ediciones Universidad de Valladolid, Valladolid 
Uzquiano P, Allué E, Antolín F et al (2014) All about yew: on the trail of Taxus baccata in SW Europe by means of integrated archaeobotanical and ethnographical studies. Veget Hist Archaeobot. doi:10.1007/s00334-014-0475-x

Van der Veen M (2007) Formation processes of desiccated and carbonized plant remains - the identification of routine practice. J Archaeol Sci 34:968-990

Whitehouse NJ, Schulting RJ, McClatchie M et al (2013) Neolithic agriculture on the European western frontier: the boom and bust of early farming in Ireland. J Archaeol Sci. doi:10.1016/j.jas. 2013.08.009

Zapata L (2000) La recolección de plantas silvestres en la subsistencia mesolítica y neolítica. Datos arqueobotánicos del País Vasco. Complutum 11:157-169

Zapata Peña L, Baldellou Martinéz V, Del Pilar Utrilla Miranda P (2008) Bellotas de cronología neolítica para consumo humano en la cueva de Chaves (Bastarás, Huesca). IV Congreso del neolítico peninsular 1:402-410 